ISSN: 1110-5623 (Print) - 2090-0570 (Online)

\title{
PRODUCTIVE PERFORMANCE AND PHYSOLIGICAY RESPONSE OF GROWING RABBITS AS AFFECTED BY USING SUGAR BEET PULP WITH OR WITHOUT ENZYMES MIXTURE SUPPLEMENT
}

\author{
Safaa, A. Barakat, Walaa, A. Salama, Amin, H.F and Lamiaa, F. Abdel-Mawla \\ Anim. Prod. Res. Inst., Agric. Res. Center, Giza, Egypt.
}

*Corresponding author's: Safaa A.Barakat Email: safaa_ataya@yahoo.com

Received: 12/04/2021 Accepted: 25/05/2021

\begin{abstract}
This study evaluated the effect of using two dietary levels (20 or $40 \%$ of the diet) sugar beet pulp (SBP) with or without enzymes mixture supplement (Smizyme) at a level of $0.3 \mathrm{~g} / \mathrm{kg}$ diet on growth performance, nutrients digestibility, some blood parameters, immune response, antioxidant activity and economic profit of growing rabbits. Seventy five weaned New Zealand White (NZW) rabbits, six weeks old, with an average live body weight $729.52 \pm 18.97 \mathrm{~g}$ were randomly divided into five groups (fifteen rabbits, each). Rabbits were fed on 5 experimental diets as follows: diet 1: A control without SBP,2, 3fed diets20 and 40\%SBPwithout enzymes mixture and 4,5 fed diets 20 and $40 \%$ SBPwith enzymes mixture .The growth trail lasted about 8 weeks. The results indicated that, inclusion of $40 \%$ SBP with enzymes mixture in rabbit diet significantly increased final body weight, daily body weight gain, improve feed conversion, relative growth rate and performance index, dressing\% and also gave the highest economical efficiency than those fed control diet. Digestibility coefficients of DM,CP, EE, NFE significantly increased with replacement 20 or $40 \%$ SBP with enzymes mixture in rabbit diets. Feeding on $40 \%$ SBP with enzymes mixture increased significantly digestibility coefficients of $\mathrm{OM}$ and CF as compared to rabbits fed control diet. Albumin/ Globulin ratio, AST and Catalase were significantly increased with replacement 20 or $40 \%$ SBP with enzymes mixture in rabbit diets compared to control. However, total cholesterol and Malondialdehyde significantly decreased with replacement $40 \%$ SBP with enzymes mixture in rabbit diet as compared with control diet. Feeding rabbits on 40\% SBP with enzymes mixture achieved significantly higher $\mathrm{IgG}$ and $\operatorname{IgM}$ than those fed control diet.

Conclusively, it could be recommended replacement sugar beet pulp SBP up $40 \%$ with enzymes mixture of the rabbit diets to improve the performance, antioxidant status, immunity functions and economic return of the growing rabbits.
\end{abstract}

Keywords: Sugar beet pulp, enzymes mixture, immunity, antioxidant and rabbits. 
Safaa, A.Barakat, et al.

\section{INTRODUCTION}

Utilization of agricultural residues from the food industries as feed ingredients for poultry are important to decrease feed cost, and improve the sustainable utilization of feed resources for poultry production. Egypt is one of the main producers of sugar beet in the world. Egypt increased the produced quantity from about 500 tons in 1961 to 2.890360 million tons in year 2000, then 13.323369 million tons harvested in 2016 (FAO, 2018).

Sugar beet pulp (SBP) is the residues collect after processing of sugar beet (Beta vulgaris L.). From the sugar industries rich by product of carbohydrate has been used as a partial source of energy in rabbit diets (Abd EL-Latif et al., 2012). Minarovicova et al., (2018) reported that sugar beet pulp is low in $\mathrm{CP}$ it is contained $10.31 \%$ protein, $0.42 \%$ fat, $3.56 \%$ ash and very high level of CF $(19.0 \%)$. Moreover, SBP is relatively high in $\mathrm{Ca}$, however, being very low in $\mathrm{P}$, $\mathrm{Se}$, vit.B and has almost no vit. $\mathrm{D}$ or the precursor of vit.A (Hagstrom, 2008). In addition, SBP is considered as potent sources of antioxidant (high content of phenolic compound, flavoids, flavonols) which can play an important role in adsorbing and neutralizing free radicals, quenching singlet and triplet oxygen or decomposing peroxides (Jeong et al., 2004). Sugar beet pulp is classified as low quality feedstuff characterized by high content of soluble fiber (19\% pectins and glucans), which is fermented primarily to acetate led to decreased cecal $\mathrm{pH}$ and the negative effect on digestion of rabbit (Hall et al., 2000).Therefore, many attempts have been done to improve its nutritive value by using the biological and enzymatic treatments. Zaza, (2005) found that The rabbits fed diets contained 50 and $75 \%$ biologically treated sugar beet pulp replacement with yellow corn were significantly higher in the average daily weight gain than control. In growing rabbits fed diet sugar beet pulp supplemented with exogenous digestive enzymes (Kemzyme is multi enzyme contain Xylanase, beta glucans and cellulose) improved digestive activities and growth rate, average weight gain and morphology of intestinal mucosa also the feed conversion ratio improved by $3.36 \%$ than those fed diets without Kemzyme,(Attia et al., 2012 and ElTahan et al.,2019).

Therefore, the objective of the present study was to investigate and improve nutritive value of sugar beet pulp by supplemented enzymes mixture and use it in growing rabbit diets at two levels 20 or $40 \%$ of the diets and its impact on rabbit's growth performance, digestibility, some blood parameters and economic profit.

\section{MATERIALS AND METHODS}

The present study was carried out in rabbit research unit at Borg El Arab Research Station located in Alexandria governorate, Egypt, belongs to Animal Production Research Institute, Agricultural Research Center.

\section{Sugar beet pulp and Enzymes mixture} Sugar beet pulp (SBP) was purchased from local commercial company, Alexandria, Egypt. The enzymes mixture were Smizyme, Beijing Smile feed Science and Technology. Development Company, China. Each 1 gram of the mixture contained (betaglucanase 3000U,Pectinase 200U, Cellulase, 250 U, Protease 2000U, Xylanase 7000U and Mannase 100U).

\section{Experimental design and diets}

Seventy five weaned NZW rabbits were divided randomly into 5 experimental groups of 15 rabbits each at 6 weeks of 
Sugar beet pulp, enzymes mixture, immunity, antioxidant and rabbits.

age with an average live body weight of $(729.52 \pm 18.97 \mathrm{gm})$. The experimental groups were: 1 control (basal diet) withoutSBP,2, 3 fed diets containing 20 and $40 \%$ SBP without enzymes mixture and 4, 5 fed diets containing 20 and $40 \%$ SBP with (Smizyme) enzymes mixture(at a level of $0.3 \mathrm{~g} / \mathrm{kg}$ diet). Rabbits were housed in individual galvanized wire pyramidal batteries ( $30 \times 25 \times 35 \mathrm{~cm}$ ) with feeder and automatic nipple drinkers. The batteries were arranged in rows in a windowed house naturally ventilated. All rabbits were kept under the same management conditions. Feed and water were supplied ad libitum. All the experimental diets were formulated to be isonitrogenous and isocaloric, to meet all the essential nutrient requirements of growing rabbits according to Egyptian Agriculture Ministry Decree (1996).Ingredients and chemical analysis of experimental diets are presented in table 1. Also, digestible energy (DE, Kcal/g) of sugar beet pulp was calculated according to Cheeke (1987), DE $(\mathrm{kcal} / \mathrm{g})=4.36-0.0491 \mathrm{x}$ NDF, Where NDF\% $=28.924+0.657 \mathrm{x}$ CF\%; CF crude fiber, NDF: Neutral detergent fiber.

\section{Growth performance}

Live body weight was recorded weekly from 6 to 14 weeks of age and daily body weight gain was calculated. Feed intake (FI) was determined as grams per rabbit per week. Feed conversion ratio (FCR) was calculated as a ratio of gram of feed per gram of gain. Relative growth rate and performance index were calculated according to North, (1981).

Relative growth rate $=\left[\left(\mathrm{W}_{2}-\mathrm{W}_{1}\right) \times 100\right] /$ $\left[1 / 2\left(\mathrm{~W}_{2}+\mathrm{W}_{1}\right)\right]$, Where: $\mathrm{W}_{1}=$ Initial body weight $(\mathrm{g})$, and $\mathrm{W}_{2}=$ Final body weight (g).

Performance index $(\mathrm{PI})=($ Final live body weight $(\mathrm{kg}) /$ Feed conversion ratio $) \times 100$

\section{Digestibility trails}

The experimental period lasted for 8 weeks. At the end of the experimental period, a digestibility trial was conducted to determine the digestibility coefficient of the nutrients according to Fekete (1985). Digestibility trial was carried out using four male rabbits from each experimental group at the last week of the growth experiment (14 weeks of age). The rabbits were housed in metabolic cages, where feces samples were collected separately for 6 days as a collection period, which the feces were collected daily and sprayed with $2 \%$ boric acid solution for trapping any released ammonia from feces. At the end of collection period, the feces were dried at $60^{\circ} \mathrm{C}$ for 48 hours (till constant weight), finely grounded and thoroughly mixed to ensure sample uniformity and then stored until being analyses. Proximate analysis of the sugar beet pulp, diets and feces were carried out according to the methods of A.O.A.C (2000).

\section{Carcass traits}

At the end of the experimental period, 5 rabbits were taken from each treatment and slaughtered to study carcass traits according to Biasco and Ouhayoun (1996).

\section{Blood metabolites}

Blood samples (5 rabbits of each treatment) were collected in the morning from the marginal ear vein to determine blood plasma components. Plasma was separated by centrifugation at $3000 \mathrm{rpm}$ for $15 \mathrm{~min}$ and stored at $-20^{\circ} \mathrm{C}$ until analyzed. Quantitative colorimetric determination of total protein (TP, g/dl), and albumin (Alb, $\mathrm{g} / \mathrm{dl}$ ) were executed by using kits of Stanbio Laboratory Inc, procedure No. 0280. (San Antonio, Texas, USA). Globulin concentration (Glb, g/dl) was calculated by subtracting Alb values from TP values. Albumin/ Globulin ratio (A/G ratio) was calculated for each sample. 
Safaa, A.Barakat, et al.

Quantitative colorimetric determination of triglycerides (TG $\mathrm{mg} / \mathrm{dl}$ ) and cholesterol $(\mathrm{mg} / \mathrm{dl})$ were executed by using kits of Spinreact, S.A./S.A.U. Ctra. Santa Coloma, 7 E-17176 SANT ESTEVE DE BAS (GI) SPAIN. The quantitative immunological determination of immunoglobulin G, immunoglobulin $\mathrm{A}$ and immunoglobulin $\mathrm{M}$ in plasma on COBAS INTEGRA by Roche Diagnostics GmbH, SandhoferStrasse116, D-68305 Mannheim, USA .

Kits from Diamond for lab technology (Heliopolis, Cairo - Egypt) were used in determination of concentrations $(\mathrm{mg} / \mathrm{dl})$ of urea and creatinine as indicators for kidney functions. Activities of aspartate aminotransferase (AST) and alanine aminotransferase (ALT) as indicators for liver functions were determined calorimetrically using kits supplied by QSlap, ElQasar El Ainy St, Cairo -Egypt). All determinations were performed according to the procedures outlined by the respective manufacturers. Malondialdehyde (MDA) and catalase (CAT) were calorimetrically determined using commercial kits (purchased from Bio-Diagnostic, Cairo, Egypt, according to the manufacturers' instructions).

\section{Economical efficiency}

The economic efficiency of the experimental diets for body weight gain, calculated by the costs of feed required for producing $1 \mathrm{~kg}$ of body weight gain. The total cost of the diets calculated by the Egyptian pound L.E in the local market at the time of the experiment. The economical efficiency (EEF) was calculated according to the following equation:

$\mathrm{EEF}=$ Net revenue $/$ total costs.

\section{Statistical analysis}

The differences between experimental treatments were statistically analyzed using the general linear model (GLM) procedures of SAS (2004), by applying one-way analysis of variance (ANOVA). All results were analyzed using the following statistical model: $Y i j=\mu+\mathrm{Ti}+$ eij, Where: $Y i j=$ the observation of $\mathrm{ij} ; \mu=$ Overall mean; $\mathrm{Ti}=$ Effects of, i (treatments) and eij=Experimental random error. The significant differences between treatments means were separated by Duncan's multiple range test(Duncan, 1955).

\section{RESULT AND DISCUSSION}

\section{Chemical composition of sugar beet} pulp

Chemical analysis of sugar beet pulp (SBP) is shown in Table 2, which revealed that sugar beet pulp had low content of crude protein and EE. The values were being $8.18 \%$ and $0.78 \%$, respectively. In adverse sugar beet pulp had high content of DE, CF, NFE and Ash. The values were 2360, 18.28, 66.64 and 6.12 , respectively. The chemical composition of SBP is ranging from 9.33 to $10.71 \%$ for $\mathrm{CP}, 0.10$ to $2.40 \%$ for $\mathrm{EE}$, 18.40 to $22.37 \%$ for $\mathrm{CF}, 59.34$ to $65.69 \%$ for NFE and 3.25 to $6.67 \%$ for ash on DM basis (Ali et al., 2000; Talha et al., 2002; El-Badawi et al., 2003 and Emam (2018). The difference in the chemical composition of SBP may be due to the drying method or the amount of molasses added to the pulp.

\section{Growth performance}

The influence of fed experimental diets on growth performance is illustrated in Table 3. Sugar beet pulp with or without enzymes diets increased final body weight than those fed control diet. Also, 40\%SBP in diet with enzymes significantly increased final body weight than control diet. Although, no significant differences could be observed between 20\%SBP diets with or without enzymes and diet containing 40\%SBP without enzymes as compared with those fed control diet. While there were significant decrease in final body weight when rabbits 
Sugar beet pulp, enzymes mixture, immunity, antioxidant and rabbits.

fed on $40 \%$ SBP without enzymes compared to feeding $40 \%$ SBP with enzymes. The daily body weight gain significantly increased with feeding on $40 \%$ then $20 \%$ SBP with enzymes in rabbit diets, then $20 \%$ SBPwithout enzymes as compared with rabbits fed control diet. However, there was no significant difference in daily feed intake by feeding SBP with or without enzymes and those rabbits fed control diets. Feed conversion value were significantly improved with 40 or $20 \%$ SBP with enzymes as compared to rabbits fed control diet $(2.72,2.80$ and 3.37), respectively. The better relative growth rate and performance index were significantly increased with 20 or $40 \%$ SBP diets with enzymes as compared to rabbits fed control diet. Generally, feeding rabbits on $40 \%$ SBP with enzymes in rabbit diet significantly increased final body weight, daily body weight gain, improve feed conversion, relative growth rate and performance index. The improvement in live body weight and body weight gain in rabbits fed SBP with exogenous digestive enzymes (Kemzyme is multi enzyme contain Xylanase, beta glucans and cellulose) may be due to degradation glucans found in SBP there for improved digestive enzyme activities and morphology of intestinal mucosa coupled with high growth rate (Attia et al., 2012).The improvement in live body weight and body weight gain with sugar beet pulp with compared to control may be related to the powerful antioxidant which can protect biological systems against the oxidative stress as shown in Table 8 (Jeong et al., 2004). Final body weight and weight gain decreased in animals fed diets high in SBP without supplemental enzymes when it compared to SBP diet with external supplemental enzymes may be related to high SBP content of soluble fiber (pectins, glucans), which is fermented primarily to acetate led to decreased cecal $\mathrm{pH}$ and its negative effect on digestion of rabbit (Hall et al., 2000).These results are in agreement with El-Abed et al., (2011)who found that inclusion of SBP increased the ileal viscosity and decreased the cecal $\mathrm{pH}$.
This result agree El-Tahan et al., (2019) who reported that rabbits fed diets with 50\%sugar beet pulp and 50\% sugar beet pulp with Kemzyme recorded the highest values of daily weight gain, relative growth rate and performance index than those fed control diet. Also, feed conversion ratio was significantly improved with rabbits fed sugar beet pulp diets. Moreover, rabbits fed diets with Kemzyme improved feed conversion ratio by $3.36 \%$, but with no significant effect on final body weight and daily weight gain as compared with those fed control diets. Also, Abd EL-Latif et al., (2012) recorded significant increase in body weight in rabbits fed diets containing 25, 50 and 100\% sugar beet pulp replaced of berseem hay than those fed control diet. Also, rabbits fed 25\% SBP recorded the best feed conversion compared with other dietary treatments. Salah El-Din et al.,(2016) indicated that body weight was significantly increased while body weight gain insignificantly increased with increasing sugar beet pulp in the diets up to $75 \%$ substitution for yellow corn grain(27\% sugar beet pulp in the diet). However, daily feed intake was insignificantly decreased with increasing the level sugar beet pulp up to $100 \%$. The better feed conversion were observed in rabbits fed diets for sugar beet pulp substituted yellow corn grain $(25,50$ and $75 \%$ ) as compared to control group.

\section{Digestibility coefficients of diets}

Results of digestibility coefficients of nutrients of experimental diets are presented in Table 4, and showed that digestibility coefficients of DM, CP, EE and NFE were increased significantly with inclusion $40 \%$ SBP with enzymes in rabbits diets compared to rabbits fed control diet. While, using of $40 \%$ SBP without enzymes significantly decreased digestibility coefficients of $\mathrm{CP}$, NFE compared to enzymes supplemented treatments. Also, there were significant increase in digestibility coefficients of $\mathrm{OM}$ and $\mathrm{CF}$ for rabbits with inclusion $40 \%$ SBP with enzymes as compared to 
Safaa, A.Barakat, et al.

rabbits fed control diet. On the other hand, digestibility coefficients $\mathrm{OM}$ and $\mathrm{CF}$ was significantly decreased for group received $40 \%$ SBP without enzymes as compared to group fed the same SBP level with enzymes. However, there was no significant difference in all digestibility coefficients when replacement of $40 \%$ SBP without enzymes and control diet. Generally, the results showed great improvement in digestibility \% of CP, CF, EE and NFE of $40 \%$ SBP supplemental enzymes group. This improvement of the digestibility and utilization of nutrients in diets lead to improvement in growth rates and weights table (3). In this respect, Yan et al., (2017) found that nutrient digestibility was improved by increasing level of sugar beet pulp supplementation (up to $12 \%$ ) in weaning pig diets. El-Taweel (2010) indicated that, inclusion of 50\% sugar beet pulp instead of grains in diet had no effect on DM and OM digestibility \%. Also, Abd El-Latif et al., (2012) recorded that a significant differences in the digestibility of $\mathrm{CP}$ and $\mathrm{CF}$ for rabbit fed 50 and $75 \%$ sugar beet pulp replacement of berseem hay compared with control diet with no significant effect in the digestibility of DM, OM, EE and NFE when using sugar beet pulp as a replacement of berseem hay in rabbit diets compared with control diet. In contrast, Salah El-Din et al., (2016) found that replacing yellow corn with SBP up to $75 \%$ had a significant improve in digestibility coefficients of DM, CP and NFE. Digestibility coefficients of $\mathrm{OM}$ was gradually increased $(\mathrm{P}<0.01)$, while digestibility coefficients of $\mathrm{CF}$ was decreased gradually $(\mathrm{P}<0.01)$ with increasing the level of sugar beet pulp up to $100 \%$ substitution of yellow corn grain. Also,
El-Badawi et al., (2007) Showed that the rabbits fed either 25 or $50 \%$ treated SBP with Trichoderma reesei showed significantly $(\mathrm{P}<0.05)$ better values than those fed control or 25 and $50 \%$ untreated SBP in nutrients digestibility. Zaza (2005) found that rabbits fed $75 \%$ biologically treated SBP replacement of corn grain was significantly superior in the digestibility of $\mathrm{DM}, \mathrm{OM}, \mathrm{CP}, \mathrm{CF}$ and NFE of the tested rations followed by group fed $50 \%$ biologically treated sugar beet pulp as compared to the control.

\section{Carcass characteristics}

Results of effect of experimental treatments on carcass traits of growing rabbits are showed in Table 5. The presented results showed that among studied carcass traits, only values of carcass, wt $\%$ and dressing \% were affected by experimental treatments. carcass, wt $\%$ was significantly increased with 40\% SBP supplemental enzymes than those of control diet group. Also, dressing weight percentage (carcass, wt $\%+$ edible giblets \%) was significantly increased with both inclusion levels of 20 and $40 \%$ SBP supplemental enzymes as compared with control fed diets. However, no significant effect was recorded in the edible giblets (liver, heart, kidney, spleen), head, cecum length and intestinal length among rabbits fed different experimental diets. The improvement in carcass \% and dressing $\%$ in all rabbits fed diets containing SBP compared with rabbits fed control diet is matching with the improvement of both body weight gain and digestibility of nutrients especially CP. (Tables 3 \& 4). These results agree with the conclusion of Abd El-Latif et al.,(2012) who reported an improvement in carcass weight and dressing weight \% when rabbits fed diets with sugar beet pulp and 
Sugar beet pulp, enzymes mixture, immunity, antioxidant and rabbits.

the best carcass weight was recorded in rabbits fed diets $25 \%$ and $50 \%$ sugar beet pulp as compared with control diets. In this concern, El-Badawi et al., (2007) showed high dressing percentage and significant increase in liver, kidneys and heart $\%$ for growing rabbits fed 25 and 50 $\%$ treated sugar beet pulp with Trichoderma reesei compared with rabbits fed control and $25 \%$ untreated sugar beet pulp diets. On the other hand Sayed et al., (2019) indicated that no significant differences on carcass weight and dressing weight percentage between rabbits fed diets sugar beet pulp(with or without enzyme) and with those fed control diets, also, adding enzyme to sugar beet pulp had no significant effect on carcass and dressing weight. Also, Abedo et al.,(2012) recorded significant decrease $(\mathrm{P} \leq 0.01)$ in carcass weight and dressing percentage with higher values $(\mathrm{P} \leq 0.05)$ for heart and kidneys in 25 or $50 \%$ sugar beet pulp groups than control.

\section{Blood constituents}

The presented results of effect of experimental treatments on blood parameters of growing rabbits in Table 6 , indicated that no adverse effect of dietary SBP with or without enzyme supplementation on total protein, albumin, globulin, ALT, value of urea-N, creatinine and triglyceride. However, it could be observed significant differences in plasma AST activities in rabbits fed 20 or $40 \%$ SBP with enzymes and $20 \%$ SBP without enzymes as compared to rabbits fed control diet. Also, values of A/G ratio were significantly increased with inclusion of 20 or $40 \%$ SBP with enzymes compared to rabbits fed control diet. Furthermore, total cholesterol significantly decreased with fed on $40 \%$ SBP with enzymes compared with that rabbits fed control diet (33.36 and
$59.30 \mathrm{mg} / \mathrm{dl}$ ) respectively. The reduction in blood cholesterol may be due to the decrease in the activity of enzyme synthesis, as recorded by Chowdhury et al., (2002).The obtained values of blood parameters were in the normal biological ranges which indicated that growing rabbits were in good health status. These values are similar to those cited by Ganong (2005). Plasma proteins are part of the immune response where antibodies are made of albumin which is the major protein constituent of serum and globulins are carrier proteins to steroid and thyroid hormones and play role in natural immunity to infection. Zaza (2005) found that no significant differences between the rabbits fed biological treated sugar beet pulp and control in total protein, albumin, globulin, A/G ratio, AST and ALT while, rabbits fed $50 \%$ treated SBP ration recorded high $(\mathrm{p}<0.05)$ urea concentration as compared with those fed either the $75 \%$ treated sugar beet pulp or control diets. Also, Abd El-Latif et al.,(2012) recorded a significant differences on total protein, albumin and globulin, when using 50\% and $75 \%$ sugar beet pulp in rabbit diets, and the greatest $(\mathrm{P}<0.05)$ values of blood total protein, globulin were recorded for rabbits fed dietary $100 \%$ sugar beet pulp compared with other dietary. The same result recorded by El-Badawi et al., (2007) who fed growing rabbits on untreated sugar beet pulp (USBP) or fungal treated sugar beet pulp (TSBP) with Trichoderma reesei at levels of 25 and $50 \%$ and found that, total protein, albumin, urea, creatinine, AST and ALT were within the normal range. In contrast, Yan et al., (2017) found that blood urea nitrogen concentration $\quad(p<0.05)$ decreased when pigs fed the diets with sugar beet pulp as compared with control 
Safaa, A.Barakat, et al.

group. The same result by Abedo et al., (2012) who recorded decrease in Urea-N and creatinine in rabbits fed diet containing $20 \%$ and $50 \%$ sugar beet pulp as compared to those fed control diets. Akbari and Torki (2014) suggested that the high concentration of antioxidants decrease lipid peroxidation and then reduce the serum concentration of triglycerides.

\section{Immune response}

Results in Table 7. Showed that immunoglobin $\operatorname{IgG}$ was significantly increased in rabbits fed $20 \%$ and $40 \%$ SBP with enzymes as compared to rabbits fed control diet $(2.81,2.95$ and 2.29, respectively). This improvement in $\mathrm{IgG}$ in rabbits fed SBP compared to rabbits fed control diets which means that antibody levels were improved. Also, immunoglobin $\operatorname{IgM}$ was significantly higher in groups fed 40\% SBP with enzymes than other experimental diets. That IgM is predominantly found in the lymph fluid and blood, and it is a very effective neutralizing agent in the initial stages of disease so increased level of $\operatorname{IgM}$ can be a sign of recent infection to antigens. Results of immunoglobin $\operatorname{IgA}$ did not significant by diets. These results agree with Yan et al., (2017) who found positive effects in IgA and IgM and could be increase by increasing level of sugar beet pulp supplementation (up to 12\%) in weaning pigs diets. The first antibody involved in the mucosal immunity is IgA, which decrease intracellular pathogens association with the nonspecific innate defense system. And, the second antibody produce is immunoglobin IgM in the initial stage of antibody response (Liu et al., 2020a). Mohamed et al., (2012) found that the values of $\operatorname{IgM}$ was improved $(p<0.05)$ significantly with adding (multi enzyme) $35 \mathrm{~g} / 100 \mathrm{~kg}$ Natuzyme to $20 \%$ lemon pulp diet compared to the control group (263.35 vs 182.75). In accordance with El-Kholy et al., (2019) which reported that increased in the digestion of some nutrients in the treated groups improved the availability of circulating amino acids for immunoglobulin synthesis by B lymphocytes. Immunoglobulins are produced in B-cells in bone marrow and the biological characteristics of $\operatorname{IgG}, \operatorname{IgA}$ and $\operatorname{IgM}$ in poultry are like mammals. Present of IgG at the highest concentration was responsible for immunologic competence, so IgG can be used as an index of humoral immunity. Gao et al., (2007) reported that enzyme (xylanase) supplementation in poultry diet increased the relative weight of spleen and increased serum antibody lymphocyte. The enhancement of immune functions in treated groups, may imply SBP supplements are rich in flavonoids and phenolic compound which act as strong anti-oxidants Mohdaly et al., (2013).

\section{Antioxidant status}

The effect of feeding diets containing SBP with or without enzymes on blood antioxidant constituents of growing rabbits are presented in Table 8. Data showed that values of antioxidant activity was in the normal biological ranges which means that growing rabbits were in good health, where a significant decreased of plasma malondialdehyde (MDA)were observed in rabbits fed20,40\% SBP with enzyme and20\%SBPwithout enzymes as compared with rabbits fed control diet (2.46,2.30, 2.76 and 3.83), respectively. The opposite effect was noticed regarding catalase where the value were significantly increased in rabbits fed $40 \%$ then $20 \%$ SBP with enzymes and $20 \%$ SBP without enzymes compared with 
Sugar beet pulp, enzymes mixture, immunity, antioxidant and rabbits.

rabbits fed control diet (348.1, 335.2, 310.7 and 247.37). Increasing of catalase and decreasing of lipid peroxidation may be due to the SBP containing antioxidant substance, this interpretation is in accordance with Droge, (2002) who reported that lipid peroxidation leads to the formation of various products such as the malondialdehyde. Therefore, the level of malondialdehyde in blood is determined as an indicator to lipid peroxidation in the body. Many oxidation reactions are essential for survival in the biological system. Sometimes, inside the normal cells, oxidation reactions related to uncontrolled reactions produce unstable oxygen molecules (free radicals). These compounds react with other different important molecules in organs as lipid; protein and DNA produce a new compound which damage DNA (Ercegovac et al., 2010). Antioxidants are the first line of defense against free radical damage and for maintains to the optimum health (Lobo et al., 2010). Catalase plays a major role in protecting cells from oxidative damage; this process requires specific nutrients to be present in the diet. The obtained results in this study indicated that diets containing SBP for growing rabbits reduced the MDA levels, subsequently decreased lipid peroxidation. Also, this result agree with Akbari and Torki (2014) who suggested that the high concentration of antioxidants might decrease lipid peroxidation. Muhammad et al., (2019) cited that the high antioxidant ability of sugar beet pulp against lead-induced oxidative stress, which was induced by high glucose. High glucose caused significant lipid peroxidation in cell which was reversed by using sugar beet pulp. Mohdaly et al., (2013) and Adel et $a l$. , (2010) reported that using sugar beet pulp with different extracting solvent had the highest antioxidant activity due to its high content of phenolic compounds and flavonoids.

\section{Economical efficiency}

The effect of feeding diet containing sugar beet pulp with or without enzyme are present in Table 9. The lowest total feed cost /rabbit (13.97LE) were recorded by diet containing $40 \%$ SBP with enzymes and $40 \%$ SBP without enzymes (14.14LE) compared with control diet (14.58 LE). Also, the rabbits selling price was increased in all rabbits fed diets (40\% then $20 \%$ ) SBP with enzymes then $20 \%$ SBP without enzymes compared to control diet $(62.88 \mathrm{~g}, 60.48 \mathrm{~g}$ and $58.14 \mathrm{~g}$. vs. $48.52 \mathrm{~g}$.), respectively. This increase may be due to increased in total average weight. The same trend were recorded in net revenue (48.91, 46.19 and $42.81 \mathrm{vs.}$ 33.94LE) with containing $40 \%$ then $20 \%$ SBP with enzymes then 20\% SBP without enzyme compared to control diet. Also, the recorded results showed that the highest economical efficiency were by rabbits fed $40 \%$ and $20 \%$ SBP with enzymes (3.50 and 3.23) respectively, and the least value was shown with rabbits fed control diet (2.32). The best value of relative economic were recorded in rabbits fed diets $40 \%$ and $20 \%$ SBPwith enzymes (150.40 and138.89) respectively.

Generally, it can be observed that inclusion of 20 or $40 \%$ SBP with or without supplemental enzymes mixture based on (beta glucanase, Pectinase, Cellulase, Protease, Xylanase and Mannase) recorded the best economical efficiency than the control diets. These results were in agreement with, Zaza (2005) who reported that the highest economical efficiency was recorded by the group fed $50 \%$ biologically treated 
Safaa, A.Barakat, et al.

SBP (145.89\%) followed by group fed $75 \%$ biologically treated SBP $(115.3 \%)$ and the poorest was in the control (78.99\%). Also, El-Badawi et al., (2007) observed the highest economical efficiency were recorded in the group fed on $50 \%$ treated SBP with fungal, followed by the group that fed $75 \%$ treated SBP and then by the control group. The same result obtained by Salah El-Din et al., (2016) where the best efficiency value was recorded by the rabbits fed $75 \%$ SBP substitution of yellow corn grain , followed by 100, 50 and $25 \%$ SBP. In contrast, El-Taweel (2010) showed that, replacement all grains in diets up to $75 \%$ by SBP (30\% of total ingredients) in growing rabbits diet did not effects on the economical efficiency.

\section{CONCLUSIONS}

It can be concluded that dietary SBP significantly increased growth in growing rabbits and improve the immunity parameters. Additional improvement lipid profile, lipid peroxidation and antioxidant status were reported. The overall results support the trend of using SBP with supplemental enzymes mixture effectively particularly at the $40 \%$. 
Sugar beet pulp, enzymes mixture, immunity, antioxidant and rabbits.

Table (1): Composition and calculated chemical analysis of experimental diets.

\begin{tabular}{|c|c|c|c|c|c|}
\hline \multirow[t]{2}{*}{ Ingredients } & \multirow[t]{2}{*}{ Control } & \multicolumn{2}{|c|}{ SBP } & \multicolumn{2}{|c|}{ SBP } \\
\hline & & \multicolumn{2}{|c|}{ without enzymes } & \multicolumn{2}{|c|}{ With enzymes } \\
\hline Clover hay $(12 \% \mathrm{CP})$ & 30.00 & 20.00 & 8.00 & 20.00 & 8.00 \\
\hline SBP & ------- & 20.00 & 40.00 & 20.00 & 40.00 \\
\hline Yellow corn & 21.57 & 13.57 & 11.80 & 13.57 & 11.80 \\
\hline Wheat bran & 21.24 & 18.14 & 10.51 & 18.14 & 10.51 \\
\hline Soybean meal (44\%CP) & 21.00 & 22.10 & 23.50 & 22.10 & 23.50 \\
\hline Molasses & 3.00 & 3.00 & 3.00 & 3.00 & 3.00 \\
\hline Limestone & 0.70 & 0.70 & 0.70 & 0.70 & 0.70 \\
\hline Di calcium phosphate & 1.50 & 1.50 & 1.50 & 1.50 & 1.50 \\
\hline $\mathrm{NaCl}$ & 0.50 & 0.50 & 0.50 & 0.50 & 0.50 \\
\hline Vitamins and Minerals Premix ${ }^{1}$ & 0.30 & 0.30 & 0.30 & 0.30 & 0.30 \\
\hline DL-Methionine & 0.14 & 0.14 & 0.14 & 0.14 & 0.14 \\
\hline Anticoccidia (Diclazuril) & 0.05 & 0.05 & 0.05 & 0.05 & 0.05 \\
\hline Total & 100 & 100 & 100 & 100 & 100 \\
\hline \multicolumn{6}{|l|}{ Calculated analysis $\%{ }^{2}$} \\
\hline OM\% & 92.96 & 92.45 & 92.49 & 92.50 & 92.54 \\
\hline $\mathrm{CP} \%$ & 17.76 & 17.60 & 17.13 & 17.60 & 17.13 \\
\hline $\mathrm{CF} \%$ & 13.36 & 13.57 & 12.85 & 13.57 & 12.85 \\
\hline $\mathrm{EE} \%$ & 2.61 & 2.15 & 1.70 & 2.15 & 1.70 \\
\hline Ash\% & 7.04 & 7.55 & 7.51 & 7.50 & 7.46 \\
\hline $\mathrm{NFE} \%$ & 59.23 & 59.05 & 60.41 & 59.10 & 60.46 \\
\hline $\mathrm{DE}(\mathrm{kcal} / \mathrm{kg})$ & 2545 & 2535 & 2586 & 2535 & 2586 \\
\hline
\end{tabular}

SBP: Sugar beet pulp .

${ }^{1}$ Each $3 \mathrm{~kg}$ of vitamins and minerals mixture contains: Vit. A $6.000 .000 \mathrm{IU}$, Vit. ${ }_{1} 2000 \mathrm{mg}$, Vit.B 4 4000mg, Vit. ${ }_{3} 9.00 .000 \mathrm{IU}$, Vit E $40000 \mathrm{mg}$, Vit.K $32000 \mathrm{mg}$, Pantothenic acid $10.000 \mathrm{mg}$; Nicotinic acid, 50000g; Vit.B $62000 \mathrm{mg}$; Vit. $\mathrm{B}_{12} 10 \mathrm{mg}$, Folic acid 3000mg, Biotin $50 \mathrm{mg}$, Cu 5g, Choline, 250g,Mn8.5g, Fe 50g, , Co 0.1 g, Se 0.1 g, Zn 50 g,Iodine 0.2 g .

${ }^{2}$ According to Feed composition for Animal and Poultry Feedstuff used in Egypt (2001). 
Safaa, A.Barakat, et al.

Table (2): Chemical analysis of sugar beet pulp (SBP).

\begin{tabular}{|c|l|l|l|l|l|l|l|}
\hline Items & OM\% & CP\% & CF\% & EE\% & NFE\% & ASH\% & *DE(Kcal/kg) \\
\hline $\begin{array}{c}\text { Sugar beet } \\
\text { pulp(SBP) }\end{array}$ & 93.88 & 8.18 & 18.28 & 0.78 & 66.64 & 6.12 & 2360 \\
\hline
\end{tabular}

$* \mathrm{DE}(\mathrm{kcal} / \mathrm{g})=4.36-0.0491 \mathrm{x} \mathrm{NDF}$, Where NDF\% $=28.924+0.657 \mathrm{x}$ CF\% (according to Cheeke, 1987).

CF crude fiber, NDF: Neutral detergent fiber

Table (3): Effect of experimental diets on growth performance of growing rabbits.

\begin{tabular}{|c|c|c|c|c|c|c|c|}
\hline \multirow[t]{2}{*}{ Items (g) } & \multirow[t]{2}{*}{ Control } & \multicolumn{2}{|c|}{ SBP } & \multicolumn{2}{|c|}{ SBP } & \multirow[t]{2}{*}{ SEM } & \multirow[t]{2}{*}{ Sign. } \\
\hline & & $\begin{array}{l}20 \% \\
\text { without }\end{array}$ & $\begin{array}{c}40 \% \\
\text { nzymes }\end{array}$ & $\begin{array}{l}20 \% \\
\text { With e }\end{array}$ & $\begin{array}{r}40 \% \\
\text { zymes }\end{array}$ & & \\
\hline Initial body weight $(\mathrm{g})$ & 765.00 & 750.00 & 713.30 & 718.30 & 761.60 & 18.97 & NS \\
\hline Final body weight(g) & $1726.60^{b}$ & $1890.00^{\mathrm{ab}}$ & $1741.60^{\mathrm{b}}$ & $1905.00^{\mathrm{ab}}$ & $1995.00^{\mathrm{a}}$ & 37.07 & $*$ \\
\hline Daily body weight gain $(g)$ & $17.16^{\mathrm{b}}$ & $20.35^{\mathrm{a}}$ & $18.36^{\mathrm{b}}$ & $21.19^{\mathrm{a}}$ & $22.02^{\mathrm{a}}$ & 0.57 & $*$ \\
\hline Daily feed intake (g) & 57.89 & 63.09 & 60.17 & 59.36 & 59.99 & 0.78 & NS \\
\hline $\begin{array}{l}\text { Feed conversion ratio } \\
\text { (g feed/body g gain) }\end{array}$ & $3.37^{\mathrm{a}}$ & $3.10^{\mathrm{a}}$ & $3.27^{\mathrm{a}}$ & $2.80^{\mathrm{b}}$ & $2.72^{\mathrm{b}}$ & 0.07 & $*$ \\
\hline Relative growth rate $(\%)$ & $77.15^{\mathrm{b}}$ & $86.63^{\mathrm{ab}}$ & $83.67^{\mathrm{ab}}$ & $90.47^{\mathrm{a}}$ & $89.48^{\mathrm{a}}$ & 1.53 & $*$ \\
\hline Performance index $(\%)$ & $51.23^{\mathrm{c}}$ & $60.19^{\mathrm{bc}}$ & $53.24^{\mathrm{c}}$ & $68.03^{\mathrm{ab}}$ & $73.34^{\mathrm{a}}$ & 2.51 & $* *$ \\
\hline
\end{tabular}

SBP : Sugar beet pulp

NS: Not significant, $*:(P<0.05)$, and $* *:(P<0.01)$.

$\mathrm{a}, \mathrm{b}$ and $\mathrm{c}$ Means in the same row with different superscripts are significantly different

Table (4): Effect of experimental diets on digestion coefficient of growing rabbits.

\begin{tabular}{|l|c|c|c|c|c|c|c|}
\hline Items & Control & \multicolumn{2}{|c|}{ SBP } & \multicolumn{2}{|c|}{ SBP } & SEM & Sig. \\
& & \multicolumn{2}{|c|}{$\begin{array}{c}\mathbf{2 0 \%} \\
\text { without enzymes }\end{array}$} & \multicolumn{2}{|c|}{$\begin{array}{c}\mathbf{2 0 \%} \\
\text { with enzymes }\end{array}$} & & \\
\hline Dry matter(DM) & $61.60^{\mathrm{b}}$ & $65.17^{\mathrm{ab}}$ & $63.30^{\mathrm{ab}}$ & $67.33^{\mathrm{a}}$ & $68.41^{\mathrm{a}}$ & 0.90 & $* *$ \\
Organic matter(OM) & $60.24^{\mathrm{b}}$ & $64.17^{\mathrm{ab}}$ & $60.31^{\mathrm{b}}$ & $65.78^{\mathrm{ab}}$ & $67.77^{\mathrm{a}}$ & 1.06 & $* *$ \\
Crude protein (CP) & $58.88^{\mathrm{c}}$ & $67.17^{\mathrm{b}}$ & $62.40^{\mathrm{bc}}$ & $76.24^{\mathrm{a}}$ & $77.47^{\mathrm{a}}$ & 2.57 & $* *$ \\
Crude fiber (CF) & $29.56^{\mathrm{b}}$ & $31.71^{\mathrm{ab}}$ & $29.71^{\mathrm{b}}$ & $32.33^{\mathrm{ab}}$ & $43.22^{\mathrm{a}}$ & 2.57 & $*$ \\
Ether extract (EE) & $68.59^{\mathrm{b}}$ & $78.63^{\mathrm{a}}$ & $72.30^{\mathrm{ab}}$ & $78.66^{\mathrm{a}}$ & $80.06^{\mathrm{a}}$ & 1.64 & $*$ \\
Nitrogen free extract (NFE) & $60.05^{\mathrm{c}}$ & $67.75^{\mathrm{ab}}$ & $64.47^{\mathrm{bc}}$ & $71.56^{\mathrm{a}}$ & $74.16^{\mathrm{a}}$ & 1.53 & $* *$ \\
& & & & & & &
\end{tabular}

SBP : Sugar beet pulp

NS: Not significant, $*:(P<0.05)$, and $* *:(P<0.01)$.

$\mathrm{a}, \mathrm{b}$ and $\mathrm{c}$ Means in the same row with different superscripts are significantly different. 
Sugar beet pulp, enzymes mixture, immunity, antioxidant and rabbits.

Table (5): Effect of experimental diets on carcass characteristics of growing rabbits.

\begin{tabular}{|c|c|c|c|c|c|c|c|}
\hline \multirow[t]{2}{*}{ Items (g) } & \multirow[t]{2}{*}{ Control } & \multicolumn{2}{|c|}{ SBP } & \multicolumn{2}{|c|}{ SBP } & \multirow[t]{2}{*}{ SEM } & \multirow[t]{2}{*}{ Sig. } \\
\hline & & $\begin{array}{c}20 \% \\
\text { withou }\end{array}$ & $\begin{array}{c}40 \% \\
\text { nzymes }\end{array}$ & $\begin{array}{c}20 \% \\
\text { with }\end{array}$ & $\begin{array}{r}40 \% \\
\text { ymes }\end{array}$ & & \\
\hline Carcass, wt \% & $48.21^{b}$ & $50.29^{\mathrm{ab}}$ & $50.06^{\mathrm{ab}}$ & $50.97^{\mathrm{ab}}$ & $51.32^{\mathrm{a}}$ & 0.43 & ** \\
\hline Liver\% & 2.40 & 2.49 & 2.36 & 2.50 & 2.79 & 0.07 & NS \\
\hline Heart $\%$ & 0.2977 & 0.308 & 0.297 & 0.3126 & 0.322 & 0.009 & NS \\
\hline Kidney\% & 0.630 & 0.635 & 0.636 & 0.647 & 0.694 & 0.01 & NS \\
\hline Spleen \% & 0.0299 & 0.0394 & 0.0353 & 0.0397 & 0.0478 & 0.004 & NS \\
\hline Edible giblets $\%$ & 3.35 & 3.47 & 3.32 & 3.49 & 3.85 & 0.07 & NS \\
\hline Head \% & 5.61 & 5.64 & 5.76 & 5.81 & 5.89 & 0.04 & NS \\
\hline Dressing \% & $57.17^{\mathrm{b}}$ & $59.40^{\mathrm{ab}}$ & $59.14^{\mathrm{ab}}$ & $60.27^{\mathrm{a}}$ & $61.06^{\mathrm{a}}$ & 0.48 & $* *$ \\
\hline Cecum length(cm) & 48.00 & 49.00 & 48.33 & 47.33 & 50.33 & 0.60 & NS \\
\hline Intestinal length $(\mathrm{cm})$ & 232.0 & 260.3 & 247.3 & 239.6 & 253.3 & 4.38 & NS \\
\hline
\end{tabular}

SBP : Sugar beet pulp

NS: Not significant, $*:(P<0.05)$, and $* *:(P<0.01)$.

$a, b$ and $c$ Means in the same row with different superscripts are significantly different.

Table (6): Effect of experimental diets on blood parameters of growing rabbits.

\begin{tabular}{|c|c|c|c|c|c|c|c|}
\hline \multirow[t]{2}{*}{ Items } & \multirow[t]{2}{*}{ Control } & \multicolumn{2}{|c|}{ SBP } & \multicolumn{2}{|c|}{ SBP } & \multirow[t]{2}{*}{ SEM } & \multirow[t]{2}{*}{ Sig. } \\
\hline & & $\begin{array}{c}20 \% \\
\text { without }\end{array}$ & $\begin{array}{c}40 \% \\
\text { nzymes }\end{array}$ & $\begin{array}{l}20 \% \\
\text { with e }\end{array}$ & $\begin{array}{r}40 \% \\
\text { zymes }\end{array}$ & & \\
\hline Total protein $(\mathrm{g} / \mathrm{dl})$ & 4.65 & 4.80 & 4.70 & 4.90 & 4.93 & 0.07 & NS \\
\hline Albumin ( g/dl) & 3.23 & 3.43 & 3.33 & 3.56 & 3.60 & 0.07 & NS \\
\hline Globulin( g/dl) & 1.42 & 1.37 & 1.37 & 1.34 & 1.33 & 0.042 & NS \\
\hline $\mathrm{A} / \mathrm{G}$ ratio & $2.27^{\mathrm{b}}$ & $2.50^{\mathrm{ab}}$ & $2.43^{\mathrm{ab}}$ & $2.65^{\mathrm{a}}$ & $2.70^{\mathrm{a}}$ & 0.05 & $*$ \\
\hline $\mathrm{AST}(\mathrm{U} / \mathrm{L})$ & $24.30^{\mathrm{b}}$ & $34.60^{\mathrm{a}}$ & $30.60^{\mathrm{ab}}$ & $35.30^{\mathrm{a}}$ & $37.60^{\mathrm{a}}$ & 1.50 & $* *$ \\
\hline ALT(U/L) & 39.67 & 40.33 & 39.60 & 41.66 & 43.33 & 1.18 & NS \\
\hline Creatinine (mg/ dl) & 1.00 & 0.83 & 0.90 & 0.80 & 0.73 & 0.04 & NS \\
\hline Urea $\mathrm{N}, \mathrm{mg} / \mathrm{dl}$ & 24.50 & 27.00 & 27.00 & 28.30 & 30.00 & 1.53 & NS \\
\hline Total cholesterol (mg/ dl) & $59.30^{\mathrm{a}}$ & $46.33^{\mathrm{ab}}$ & $53.66^{\mathrm{ab}}$ & $43.30^{\mathrm{ab}}$ & $33.36^{\mathrm{b}}$ & 3.48 & $* *$ \\
\hline Triglyceride mg/ dl) & 123.6 & 103.0 & 121.3 & 103.0 & 93.67 & 5.78 & NS \\
\hline
\end{tabular}

SBP : Sugar beet pulp

NS: Not significant, $*:(P<0.05)$, and $* *:(P<0.01)$.

$a, b$ and $c$ Means in the same row with different superscripts are significantly different. 
Safaa, A.Barakat, et al.

Table (7): Effect of experimental diets on immune response of growing rabbits.

\begin{tabular}{|c|c|c|c|c|c|c|c|}
\hline \multirow[t]{2}{*}{ Items } & \multirow[t]{2}{*}{ Control } & \multicolumn{2}{|c|}{ SBP } & \multicolumn{2}{|c|}{ SBP } & \multirow[t]{2}{*}{ SEM } & \multirow[t]{2}{*}{ Sig. } \\
\hline & & $\begin{array}{c}20 \% \\
\text { withou }\end{array}$ & $\begin{array}{l}40 \% \\
\text { zymes }\end{array}$ & $\begin{array}{l}20 \% \\
\text { Witl }\end{array}$ & $\begin{array}{l}40 \% \\
\text { ymes }\end{array}$ & & \\
\hline $\mathrm{IgG}(\mathrm{mg} / \mathrm{ml})$ & $2.29^{b}$ & $2.78^{\mathrm{ab}}$ & $2.62^{\mathrm{ab}}$ & $2.81^{\mathrm{a}}$ & $2.95^{\mathrm{a}}$ & 0.09 & $* *$ \\
\hline $\operatorname{IgA}(\mathrm{mg} / \mathrm{ml})$ & 0.32 & 0.33 & 0.32 & 0.34 & 0.35 & 0.005 & NS \\
\hline $\operatorname{IgM}(\mathrm{mg} / \mathrm{ml})$ & $1.30^{\mathrm{b}}$ & $1.60^{\mathrm{b}}$ & $1.56^{\mathrm{b}}$ & $2.00^{\mathrm{ab}}$ & $2.40^{\mathrm{a}}$ & 0.13 & $* *$ \\
\hline
\end{tabular}

SBP : Sugar beet pulp

NS: Not significant, $*:(P<0.05)$, and $* *:(P<0.01)$.

$\mathrm{a}, \mathrm{b}$ and $\mathrm{c}$ Means in the same row with different superscripts are significantly different

Table (8): Effect of experimental diets on antioxidant activity of blood of growing rabbits.

\begin{tabular}{|l|c|c|c|c|c|c|c|}
\hline & Control & \multicolumn{2}{|c|}{ SBP } & \multicolumn{2}{|c|}{ SBP } & SEM & Sig. \\
& & \multicolumn{2}{|c|}{$\begin{array}{c}\mathbf{2 0 \%} \\
\text { without enzymes }\end{array}$} & \multicolumn{2}{|c|}{$\begin{array}{c}\text { w0\% } \\
\text { with enzymes }\end{array}$} & & \\
\hline $\begin{array}{l}\text { Malondialdehyde } \\
\text { (MDA) nmol/ml }\end{array}$ & $3.83^{\mathrm{a}}$ & $2.76^{\mathrm{b}}$ & $3.40^{\mathrm{a}}$ & $2.46^{\mathrm{b}}$ & $2.30^{\mathrm{b}}$ & 0.16 & $* *$ \\
Catalase (U /l) & $247.37^{\mathrm{c}}$ & $310.7^{\mathrm{ab}}$ & $280.7^{\mathrm{bc}}$ & $335.2^{\mathrm{a}}$ & $348.1^{\mathrm{a}}$ & 11.44 & $* *$ \\
\hline
\end{tabular}

SBP : Sugar beet pulp

NS: Not significant, $*:(P<0.05)$, and $* *:(P<0.01)$.

$\mathrm{a}, \mathrm{b}$ and $\mathrm{c}$ Means in the same row with different superscripts are significantly different $(\mathrm{P}<0.05)$.

Table (9): Economical efficiency of experimental diets of growing rabbits.

\begin{tabular}{|c|c|c|c|c|c|}
\hline \multirow[t]{2}{*}{ Items } & \multirow[t]{2}{*}{ Control } & \multicolumn{2}{|c|}{ SBP } & \multicolumn{2}{|c|}{ SBP } \\
\hline & & $\begin{array}{r}20 \% \\
\text { Witho }\end{array}$ & $\begin{array}{c}40 \% \\
\text { nzymes }\end{array}$ & $\begin{array}{r}20 \% \\
\text { with }\end{array}$ & $\begin{array}{r}40 \% \\
\text { ymes }\end{array}$ \\
\hline Total average weight gain (g) & 951.52 & 1.140 & 1.028 & 1.186 & 1.233 \\
\hline Selling price/rabbit (LE) (A) & 48.52 & 58.14 & 52.42 & 60.48 & 62.88 \\
\hline Total feed intake & 3.241 & 3.533 & 3.369 & 3.324 & 3.359 \\
\hline Price/kg feed(LE) & 4.50 & 4.34 & 4.20 & 4.30 & 4.16 \\
\hline Total feed cost/rabbit (LE), (B) & 14.58 & 15.33 & 14.14 & 14.29 & 13.97 \\
\hline Net revenue $(\mathrm{LE})^{1}$ & 33.94 & 42.81 & 38.28 & 46.19 & 48.91 \\
\hline Economic efficiency $^{2}$ & 2.327 & 2.792 & 2.707 & 3.232 & 3.501 \\
\hline Relative Economic efficiency. & 100 & 119.98 & 116.30 & 138.89 & 150.45 \\
\hline
\end{tabular}

SBP : Sugar beet pulp

Price of $1 \mathrm{~kg}$ live body weight $=51 \mathrm{LE}$

(1) Net revenue $=\mathrm{A}-\mathrm{B}$.

(2) Economic efficiency $=(A-B / B)$.

(3) Relative Economic Efficiency= Economic efficiency of treatments other than the control/

Economic efficiency of the control group. 


\section{REFERENCES}

Abd EL-Latif, S.A.; Toson, M.A.; EL Bogdadi, A. H. and Abdel-Rahman, M. K.H. 2012.Effect of replacing hay by sugar beet pulp in growing rabbit diets on some productive, metabolic responses and economical efficiency. Egyptian Journal of Animal Production. 47 Suppl. Issue, Nov. 141-149.

Abedo, A.A.; El-Badawi, A.Y. and Hassan, A.A. 2012.Sugar beet pulp as an energetic feed in growing rabbit diets. Journal of Nutrition and Feeds. 15 (3): 513-522.

Adel, A.A.M.; Mohamed, A.S; Iryna,S. and Awad, M. 2010. Antioxidant properties of various solvent extracts of potato peel, sugar beet pulp and sesame cake. Journal of Science of Food and Agricultry.90: 218-226.

Akbari, M. and Torki, M. 2014. Effects of dietary chromium picolinate and peppermint essential oil on growth performance and blood biochemical parameters of broiler chicks reared under heat stress conditions. International. Journal of Biometeorology. 58:1383-1391.

Ali, M. F; Mohsen, M.K.;Bassiouni, M. I. and Khalafaila, M.E. 2000.The influence of using dried sugar beet pulp on sheep performance. Agric. Res. Tanta Univ., 26:132

A.O.A.C. 2000.Official methods of analysis. $17^{\text {th }}$ ed., published by the A.O.A.C., Washington, D.C., USA.

Attia, K.A.; Sohair, Y. Saleh; Abd Elhamid, S.;Safaa, A. ZakiandAmal, A. El-SawyMohamed2012.Effects of exogenous multi enzyme feed additive (Kemzyme) on the activities of certain digestive enzymes and Intestinal Morphology in Growing Rabbits. Journal of Agricultural Science.4, 3.
Biasco, A. and Ouhayoun, J.1996. Harmonization of criteria and terminology in rabbit meat research. World Rabbit Science, 4: 93-99. DOI:https://doi.org/10.4995/wrs 1996.278.

Cheeke, P.R. 1987. Rabbit Feeding and Nutrition .Academic Press, Orlando, Florida USA. 376p.

Chowdhury, S.R.;Chowdhury, S.D. and Smith, T.K. 2002. Effects of dietary garlic on cholesterol metabolism in laying hens. Poultry Science, 81, 18561862.

Droge, W.2002. Free radicals in the physiological control of cell function. Physiol. Rev., 82(1): 47-95.

Duncan, D. B. 1955. Multiple range and multiple F. tests. Biometrics, 11, 1-42.

Egyptian Agriculture Ministry Decree 1996. The standard properties for ingredients, feed additives and feed manufactured for animal and poultry. El-Wakaee El-Masria, Amirria Press Cairo, Egypt. No.192,95.

El- Abed, N.; Delgado, R.; Abad, R.; Romero, C.; Fernandez, A.; Villamide, M.J.;Menoyo D.;García, J. and Carabano, R. 2011. Effect of sugar beet pulp fibre fractions on growth performance, fecal digestibility and digestive physiology in rabbits around weaning. Giornate di Coniglicoltura ASIC, 75-77.

El-Badawi, A.Y.;Yacout, M.H.M. and Kamel, H.E.M. 2003. Effect of replacing corn with sugar beet pulp on ruminal degradation kinetics and utilization efficiency of rations by growing sheep. Egyptian. Journal of Nutrition and Feeds, 6: 1349-1363.

El-Badawi, A. Y.; Hassan, A. A. and Abedo,A. A. 2007. Growth performance of new-zeal and white rabbits fed diets containing different 
Safaa, A.Barakat, et al.

levels of untreated or fungal treated sugar beet pulp. $58^{\text {th }}$ EAAP Meeting, 22 Abst. No.1170.

El-Kholy, K.H.; Tag El-Deen, H.T.; A.I. Abd-El-Lateif,A.I. and Aml I. Mekaouy2019. Effects of Dietary Selenium Sources on Metabolic, Enzymatic and Immunoglobulin Serum Profiles in Growing Rabbits. Pakistan. J. Nutr., 18: 430-436.

El-Tahan, H.M.; Sayed, M.A.M.; Morsy, W.A.; Ismail, F.S. and Elgogry,M.R.2019. Influence of using sugarcane bagasse and sugar beet pulp with or without enzymes in rabbit diets: 1- on growth performance of growing rabbits. Egyptian Journal of Nutrition and Feeds 22(2): 167-171.

El-Taweel, A.A.F. 2010. Studies on using sugar beet pulp in rabbit diets. Msc. Thesis, Faculty of Agriculture, Zagazig University, Egypt.

Emam, R.M.S. 2018. A nutritional evaluation of sugar beet pulp as untraditional feedstuffs in gimmizah chicken diets during the period from three up to eight weeks of age. Egyptian Poultry Science Journal, (38)(III): (909922).

Ercegovac, M.; Jovic, N.; Simic, T.; Beslac-Bumbasirevic, L.; Sokic, D.; Djukic T.; Savic-Radojevic, A.; Matic, M.; Mimic-Oka, J. and PljesaErcegovac, M. 2010. By-products of protein, lipid and DNA oxidative damage and antioxidant enzyme activities in seizure. Seizure, 19(4): 205210.

Feed composition for animal and poultry feed stuff used in Egypt 2001. Technical pulletilno. Centrallab. For feed and food; Ministry of agriculture. Egypt.

Fekete, S. 1985. Rabbit feeds and feeding with special regard to tropical condition.
Journal of Appl. Rabbit Res., 8: 167173.

Food and Agriculture Organization of the United Nations, FAO, 2018. http://www.fao.org/faostat/en/\#data/Q C.

Ganong, W.F. 2005. Review of medical physiology. 22 ${ }^{\text {nd }}$. New York (NY): McGraw-HillCompanies. ISBN: 978-007-160568-7.

Gao, F.; Jinang, Y.; Zhou, G.H. and Han, Z.H. 2007. The effects of xylanase supplementation on performance, characteristics of the gastrointestinal tract, blood parameters and gut microflora in broilers fed on wheat based. Animal feed Sci. Technol. diets. 142:173-184.

Hagstrom, D. J.2008. Beet pulp as a fiber source for horses. Equine Extension Specialist, University of Illinois, Written: December 2008, livestocktrail.illinois.edu > papers > beet (on line), p 1-3.

Hall, M. B.; Jennings, J. P.; Lewis, B. A. and Robertson, J. B. 2000. Evaluation of starch analysis methods of feed samples. Journal of Science Food and Agriculture. 81:17-21.

Jeong, S. Y.; Kim, D. R.; Kim, K. C.; Nam, D. U.; Ahn, L. and Lee, S. 2004. Effect of seed roasting conditions on the antioxidant activity of defatted sesame meal extracts. Food Chemistry and Toxicology. 69, 377-381.

Liu, H.; Hu, J.; Mahfuz,S. U. and Piao, X. S. 2020a. Effects of hydrolysable tannins as zinc oxide substitutes on antioxidant status, immune function, intestinal morphology, and digestive enzyme activities in weaned piglets. Animals 10; 757-770.

Lobo, V.;Patil, A.; Phatak, A. and Chandra, N. 2010. Free radicals, antioxidants and functional foods: 
Sugar beet pulp, enzymes mixture, immunity, antioxidant and rabbits.

Impact on human health. SAS 2004. SAS User's guide: Statistics.

Pharmacological Reviews, 4(8): 118.

Minarovicova, L.; Michaela, L.; Zlatica, K.; Jolana, K.; Dominika, D.; and Veronika, K. 2018. Qualitative properties of pasta enriched with celery root and sugar beet by-products. Czech J. Food Sci., 36 (1): 66-72.

Mohamed, M.H.M.; Mohmed,R.M.; ElBanna ,H.M. and Aiad,A.M. 2012. Effect of enzymes supplement on utilization of lemon and orange pulps in growing rabbit diets. P.H.D, Cairo University. Egypt.

Mohdaly, A. A.; Mohamed, F.R.H.; Awad, M.;Mohamed, A. S. and Iryna, S.2013. Phenolicsextracted from potato, sugar beet and sesame processing byProducts. International Journal of Food Properties. 16:1148-1168.

Muhammad, S.A.; mubbashar, A.; Muhammad, B.; Hassan, M.; Abdul Mannan, K.; abdulRaheem, M.; Tooba, M. and Naila, T. 2019. Protective potential of sugar beet pulp extracts (sbpe) against heavy metal induced hepato-renal toxicity in rats. international journal of biology pharmacy and Alliedscience. 8(6): 1084-1095.

North, M. O. 1981. Commercial Chicken. Production Annual.2nd Edition, Production 6th Ed. Interstate Printers and Publishers. INC., USA.

Salah El-Din, S.; Aboul-Ela. And Reda, F.M. 2016.Influence of partial and total substitution yellow corn grains with sugar beet pulp on growing rabbits performance Zagazig Journal of Agricultural Research. Vol. 43 No.(6A) 2061-2077. 


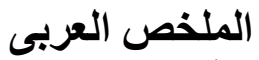

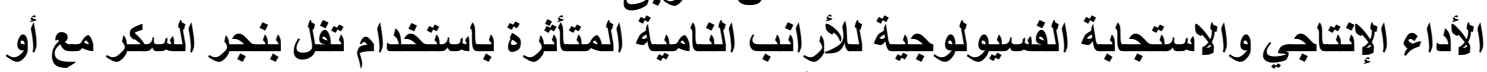

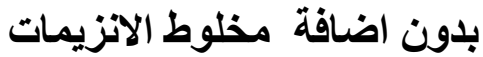

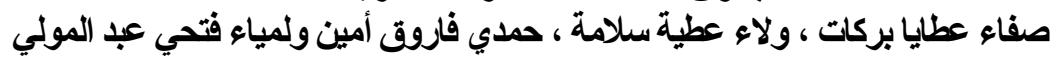

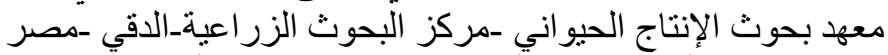

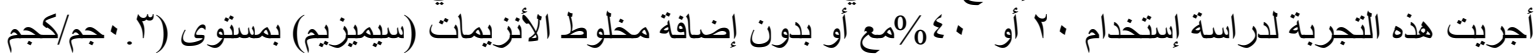

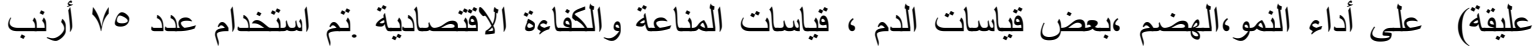

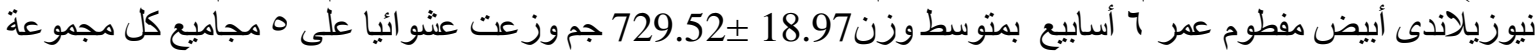

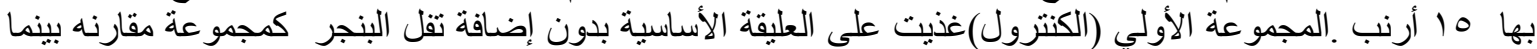

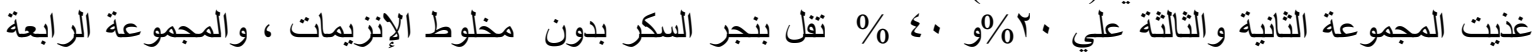

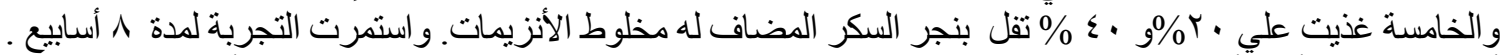

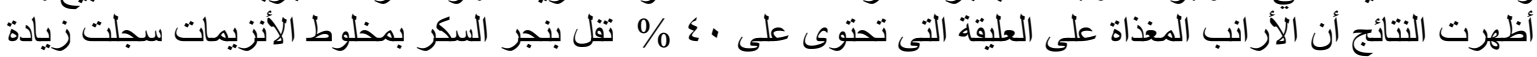

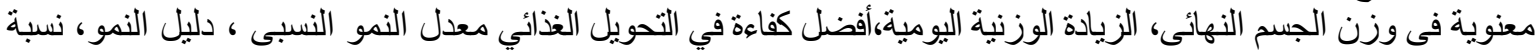

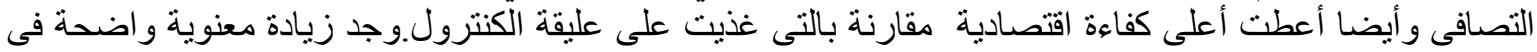

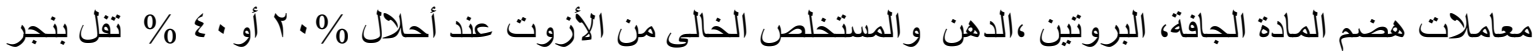

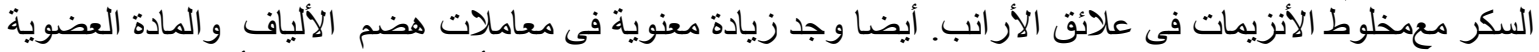

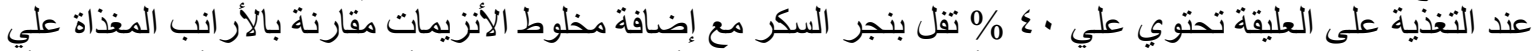

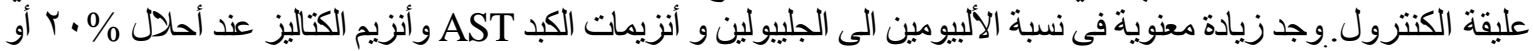

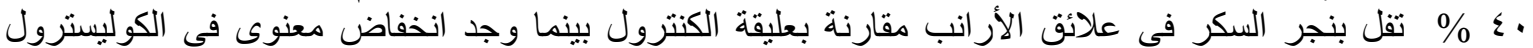

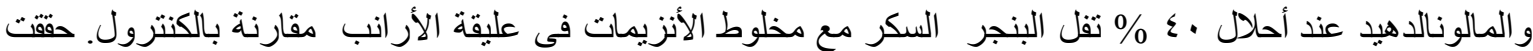

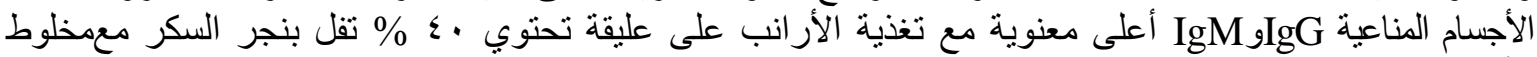
الأنزيمات مقارنة بالتى غذيت على عليقة الكنترول.

الخلاصة

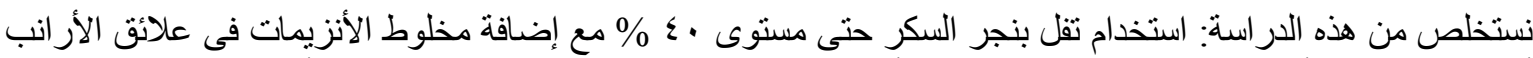
أدي إلي تحسن الأداء الإنتاجى و المو اد المضادة للأكسدة والوظائف المناعية و الكفاءة الاقتصادية للأر انب النامية. 